\title{
The Missing Faces
}

\section{Chýbajúce tváre}

\section{Terézia Tomašovičová}

\begin{abstract}
Vessels with human face application represent one of the groups from a whole set of Neolithic figurative and symbolic objects. These findings from Middle Neolithic period with few exceptions do not conform to the kind the variety and number species we encounter in Middle East and South Western Europe. Despite of this fact, it is a specific set of findings with depictions of humans, many of which by their level of artistic quality and expression of motive significantly exceed local standards. These findings used to be a subject of long lasting study in on our territory, which started at the end on 19th and beginning of 20th century. As it already implies from the title itself, identifications of this set of finds is based on anthropomorphic depiction which is applied to the surface of the pottery. The purpose of this article, however, is to emphasize that in addition to mentioned face motive, there are many additional characteristic features of face pots and their identification would offer a more complex view of the whole topic regarding ceramics with applied face motifs, especially in the light of their symbolic significance within Neolithic communities.
\end{abstract}

\section{Keywords}

Neolithic pottery - face decoration - applied motifs - Carpathian basin

\begin{abstract}
Abstrakt
Nádoby so zobrazeniami l'udskej tváre tvoria jednu zo skupín celého súboru neolitických plastík a symbolickej ornamentiky. Tieto nálezy z obdobia stredného neolitu až na pár výnimiek nedosahujú rozmanitost' ani početnost' jedincov, s ktorou sa stretávame voblasti Blízkeho Východu a juhovýchodnej Európy. Napriek tomu ide o špecifický súbor nálezov s l'udskými zobrazeniami, z ktorých viaceré svojou výtvarnou kvalitou a stvárnením motívu výrazne prevyšujú miestne štandardy. Na našom území boli predmetom dlhodobého skúmania, ktorého počiatky siahajú na prelom 19. a 20. storočia. Samozrejme, ako už z názvu vyplýva, definujúcim prvkom pre tento súbor nálezov je práve samotné antropomorfné zobrazenie. Ciel'om tohto príspevku je však poukázat' na skutočnost', že okrem spomínanej tváre existuje viacero znakov charakterizujúcich tvárové nádoby a ich identifikácia by umožnila komplexnejší náhl'ad na celú problematiku keramiky s aplikovaným tvárovým motívom, predovšetkým vo svetle ich symbolického významu v rámci neolitických komunít.
\end{abstract}

\section{Kl'účové slová}

neolitická keramika - zobrazenie tváre - aplikované motívy - Karpatská kotlina 


\section{Introduction}

Pottery with applied anthropomorphic motifs represent a specific group of artifacts characterized mainly by a large variety of species with varying degrees of stylization and schematization. Among these finds we may recognize several basic categories and sub-categories. The main criteria used for classifying is a degree of transformation of the vessel to the shape of human body, eventually its particular parts. Basic classification was presented by V. Podborský (1985, 110) who distinguished "real" anthropomorphic vessels and pottery with applied anthropomorphic motifs. At the time, both of these groups can be divided into subcategories. We should also mention a more recent work of O. Höckmann (2000-2001, 82), who categorized anthropomorphic pottery into "figuric" (Figurengefäße) with almost all of the characteristics of self-standing figurines (idols) and "figural" (Figuralgefäße), dominated by vessel-shape findings carrying only the features of human body or human depictions. The second aforementioned category is represented by finds with depictions of faces - so called face pots (vessels).

Vessels with applied face motif start appearing in the beginning of The Early Neolithic. These artifacts first occur within the archaeological context of the Starčevo-Körös-Criş cultural complex and we encounter them as a specific phenomenon of early to late Neolithic cultures (groups) during a period lasting over one millennium. They reach qualitative and quantitative apex during Middle Neolithic. Due to their large number and variety of findings, which is characteristic for this period, we are primarily focusing on specimens from this period. Related finds can be found in most cultures of Late Neolithic however in comparison with preceding period, they either create own, new forms (Svodín type vessels) or represent the surviv- ing of former middle Neolithic forms that are slowly simplified and schematized while losing their original and symbolic meaning to become ornamental decorative elements.

In spite of the fact that depictions of human beings have been discussed in Central European literature for a relatively long time, a more complex study of this phenomenons may be observed from the second half of 20th century. There were only a few researchers in this period, who dared to formulate more general theories about the cult life or eventually religious beliefs of Neolithic communities in the Carpathian basin or even Ancient Europe. A deeper analysis of relationships between specific anthropomorphic motifs and other unusual depctions, as well as the effort to compare development in georaphically larger area could be found only seldom (Quitta 1957; Makkay 1964, Kalicz - Makkay 1977; Podborský 1985). Among other researchers we would like to emphasize work of I. Pavlů (1966, 700-717) which laid firm foundations for all antecedents studying this phenomenon. There can be no doubt that one of the main reasons to avoid these subjects within the realm of pre-historic archeology of Eastern and partially Central Europe were ideological constraints and intellectual censorship caused by the effect of the Iron Curtain. On the other hand, it needs to be pointed out that many authors who published articles addressing this topic remained in the shadow of revolutionary work of M. Gimbutas (1974) - The Goddesses and Gods of Old Europe 7000-3500 BC, based on paradigm of polytheism, which is undoubtedly the most popular work concerning statuettes and anthropomorphic applied motifs from broad area of "Ancient Europe". It's obvious therefore, that studies discussing Neolithic art from our countries, as well as prehistoric belief systems only began to appear at the end of $20^{\text {th }}$ century and following decade, when we can observe a qualitative change in approaches and 
research philosophy of prehistoric archaeology (Bertemes - Biehl 2001; Garfinkel 1998, 307-237; 2010, 205-214; Hodder 1992, 207-210). We encounter application of ideas and methods of cognitivism, post-processualism, gender studies as well as exploring ethnographic parallels with special significance to the symbolic roles and religious phenomenons in past and also native communities. These general trends are, although with a slight delay, followed in our countries (Bánffy 2001, 53-71, Pavlu 1997/98, 2010; Raczky - Anders 2003, 155-182; Becker 2007, 119-127; Kalicz - Koós 2000; Podborský 2006; Remišová-Věšinová 2008, 145-175).

Despite the fact that Neolithic art has always been a subject of extensive on-going research, generally the relatively small number of ceramics with anthropomorphic applied motifs receives appropriate attention. There are still many unanswered questions regarding their origin but also in respect to understanding of their symbolic meaning and functionality in the life of individual Neolithic communities (Tomašovičová 2015). A significant problem with these finds is their fragmented state of preservation. The majority of every analyzed database consists of fragments of rims and neck parts or eventually shoulders, meanwhile bodies and whole vessels can be reconstructed only in minimum cases. It would be impossible to estimate the total number of face pots in particular areas, since we have to take into account that many fragments, which did not depict faces used to be categorized as "ordinary" ceramics.

In this respect, it would be considered a great contribution to add a new category to the group of analyzed artifacts, which has been so far left on the sidelines of scientific research or has been ignored entirely. This category represents "supposed face pots" or specimens which do not carry any signs of face depiction itself, or where these fragments are com- pletely damaged or missing, although based on other specific signs, they can be most likely considered fragments of face pots. Despite the fact that this classification has not been used in academic literature, the existence of such category of findings has been mentioned by I. Pavlů $(1997 / 98,111)$ and indirectly by a team of researchers P. Raczky and A. Anders (2003, 167). So far, no researcher has paid any systematic attention to these fragments and their potential has been completely neglected. In recent literature, we most often encounter two different approaches concerning fragments with absent face motive. In the first case, they are routinely regarded as face pots according to similar or identical archaeological contexts or morphological parameters with "real" ones (i.e. Kalicz - Koós 2000, fig. 10, 11; Hreha - Šiška 2015, 71-72, chart LX:11, LXX:9, LXXX:25, CXXII: 3; Cheben 2000, chart 37: 249/1, 123: 614/17). In the second case, fragments with missing face features are identified as ordinary ceramic material. Although the first approach is certainly more appropriate from the point of repetitive research whereas it is not possible to suppress the subjective opinion of an author, it is still necessary to establish certain specifications allowing us to take a more distinct standpoint.

It is already quite clear from the definition of face vessels that the main problem of studying phenomenon of vessels without face motive depiction is the following question: how is it going to be possible to identify a fragment as a face pot when the face itself (considered its defining feature) is absent? The aim of this article is to find answers as what criteria we should apply in order to assign the ceramic fragments to the category of face pots despite the fact that a particular fragment does not carry an anthropomorphic motive. We attempt to prove the existence of some characteristic accompanying features or signs that define the "idea" of face 
pot and distinguish them from the rest of ordinary ornamentation.

Within the context of this article, we would like to identify several characteristic features related to face depictions which are being carefully applied to create a specific composition canonical set of signs. We are convinced that these signs represent an inseparable part of the whole depiction that complements symbolic meaning of face application. These features thus create an iconographic entity that can be understood in a particular Neolithic community - even in case face depiction itself is absent.

We would like to emphasize that while some of accompanying signs (features) are spread out in many Neolithic cultures or groups simultaneously and do not change in the course centuries, others have a short-term character tied to a certain communities. Therefore with each identified sign, we are also presenting a corresponding cultural background.

\section{Typological analysis}

With regard to close correlation between researched material and so-called "real face pots", we are presenting a short characteristics of all variants of depictions occurring in the area of Carpathian basin and its surroundings during the Middle Neolithic. This study is based on evidence of 142 face pots finds from the abovementioned area. Although this database most likely does not include all existing specimens, it represents the most numerous set of face pots assembled from selected region so far. It is therefore safe to assume that it offers relatively objective information and it has unambiguous value in helping to formulate more general thesis relative to this type of findings (Tomašovičová 2015).

The question stands, to what extent is a traditional typological method applicable to ceramics with anthropomorphic applied motifs and whether applying a consistent method on such a specific set is not counter-productive. Despite substantiated doubt, it is necessary to present a brief classification corresponding to the requirements of an assembled set and also to the diversity of analyzed material. We are attempting to avoid creating a strict typology that might lead to extension of typological lines (almost any find could represent its own type) or by contrast, constriction of diversity of analyzed material (unclassified findings) due to the extreme variety found in the assembled database. Particular categories therefore represent more loosely defined variants that make provision for many criteria - from individual talent of its creator to the fact that in certain applications it was irrelevant if face pot contains a nose or how carefully individual facial features are being depicted.

\section{Variant 1 (table I: 1)}

It is defined by basic characteristic arched symbol above the face and other related motifs connected with facial features. Arched sign is a distinctive ornament composed of multiple, most often incised lines separating symmetrically into two branches above the big protruding nose which is occasionally accompanied by a short vertical line in its lower part. Eyes and mouth, as long as they are visible are depicted in the shape of horizontal grooves, or incisions. On the both sides of the face can be often found multiple incised signs, usually in the shape of horizontal letter "V" with the bottom side pointing to the face. In the case of the vessels from Berettyószentmárton-Motorva and Szelevény-Felsőföldek site (Raczky - Anders 2003, fig. 4-5) this motive is painted with black color on a red basis, but despite this the entire depiction can not be distinguished from the engraved ones. In many findings the face 
depiction itself occurred in three-dimensionally raised face area resembling a protruding triangle, half-circle or letter "V". Face vessels of this variant originate from the northern region of river Tisa and belong to the Eastern group of Linear Pottery Culture (Szatmár II, Alföld Linear Pottery, Tiszadob, Bukk culture). It is important to emphasize that this uniform complex of symbolic representation existed unchanged during more than three centuries in the Eastern part of Carpathian basin at the area of hundreds square kilometers.

\section{Variant 2 (table I: 2)}

These finds are represented by plastic, usually pronounced nose, meanwhile eyes and mouth are depicted in the form of horizontal lines. The face itself is not overlapped by any ornamental elements. All specimens originate from middle and lower regions of rivers Tisa and Danube with the exception of findings from north Hungarian SzecsényÜltetés settlemet site (Fábián 2005, 5-20, fig. 2, 4-7). We classify this material as Szakálhát culture (and related cylindrical-necked storage jar from Vinča site) and Želiezovce group. In many preserved vessels, the lower part of face is decorated by an incised "M" motive often accompanied by multiple waves or zigzag lines in its lower part. The original assumption that this symbol can be found in all face pots from Szakálhát culture (Kalicz - Makkay 1972, 10) has not been confirmed, since it does not occur in vessel from Gyoma-Özed settlement site (Goldman - Szénászky 2002, fig. 4). A unique sign we can observe especially on fragments from Želiezovce group is a distinct plastic rib framing the face from its upper part which may evoke eyebrows.

\section{Variant 3 (table I: 3)}

This group is represented by vessels with face depiction composed of plastic nose and round eyes depicted in the form of creases or engraved circles. The shape of mouth can vary - they can be depicted in the same manner as the eyes with horizontal grooves, or they can be missing completely. A curiosity is a frequent occurrence of pairs of vertical incised lines under the nose. The identifying factor is face framed in a square or a rectangle made by multiple incised lines. The complex geometric ornamentation covering the whole surface or its majority is quite conspicuous. These depictions are characteristic within the area of the Tisa ceramic style, which mean they are concentrated in Middle and Lower Tisa region (middle and southern part of The Great Hungarian Plain).

\section{Variant 4 (table I: 4)}

This group is defined by protruding plastic nose joining arched eyebrows above the bridge of the nose. The eyes are depicted in the form of elongated creases and the mouth, when a part of the face depiction, is usually represented by a circular cavity. The eyebrows in the amphora from Mohelnice site (Tichy 1958, fig. 11) are only gently suggested in contrast to eyes. Specimens of this variant have been found in Czech Republic, Moravia and lower Austria regions. The most remote fragments can be recognized in Elbe region (Lies 1963, tab. II: a). Despite of considerable distance between these areas the similarity of depictions is obvious. In all cases, we are dealing with artifacts belonging to The Transdanubian Linear Pottery culture.

In general, we can state that faces are most often applied close to the rim or in the lower 


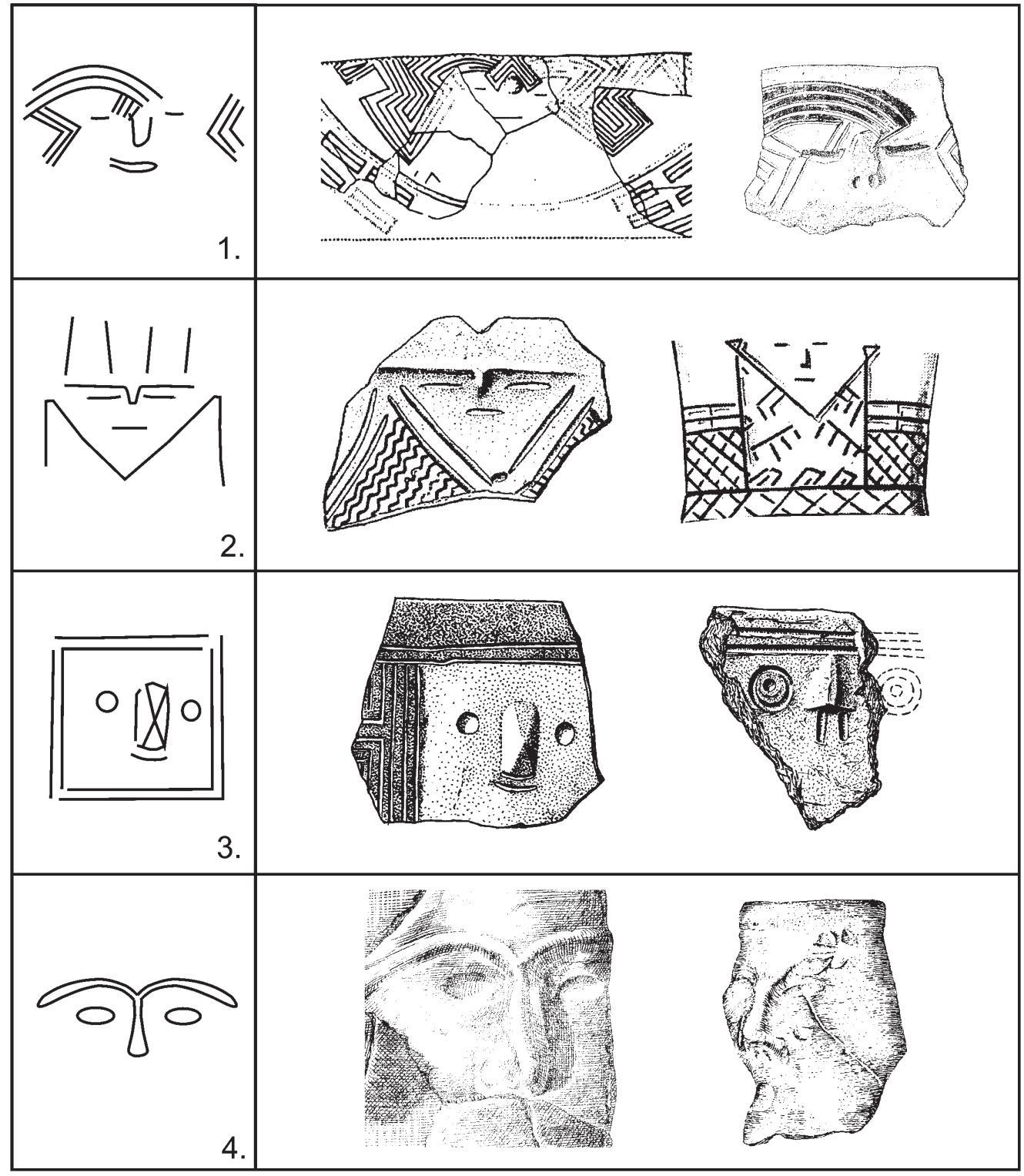

Tab. I: Variants of face depictions.

part of the neck especially of amphoras, bi-conical vessels or storage jars. In the case of deep bowls or ball-shaped vessels, the face motive occurs right under its largest bulge. A specific find comes from Blatné site (Pavík 1981, 54, fig. 39), where the face motive is applied on the handle of an amphora dating to Želiezovce group. The occurrence of a facial fragment found on the lid is also uncommon in the Carpathian basin. Fragments found at settlement site of Szakálhát culture in Battonya-Parász identified by J. Szénásky (1990, 160, fig. 1-2) represent the only artifacts of this kind in distant north, whereas she considers Central Balkan as a core area. 


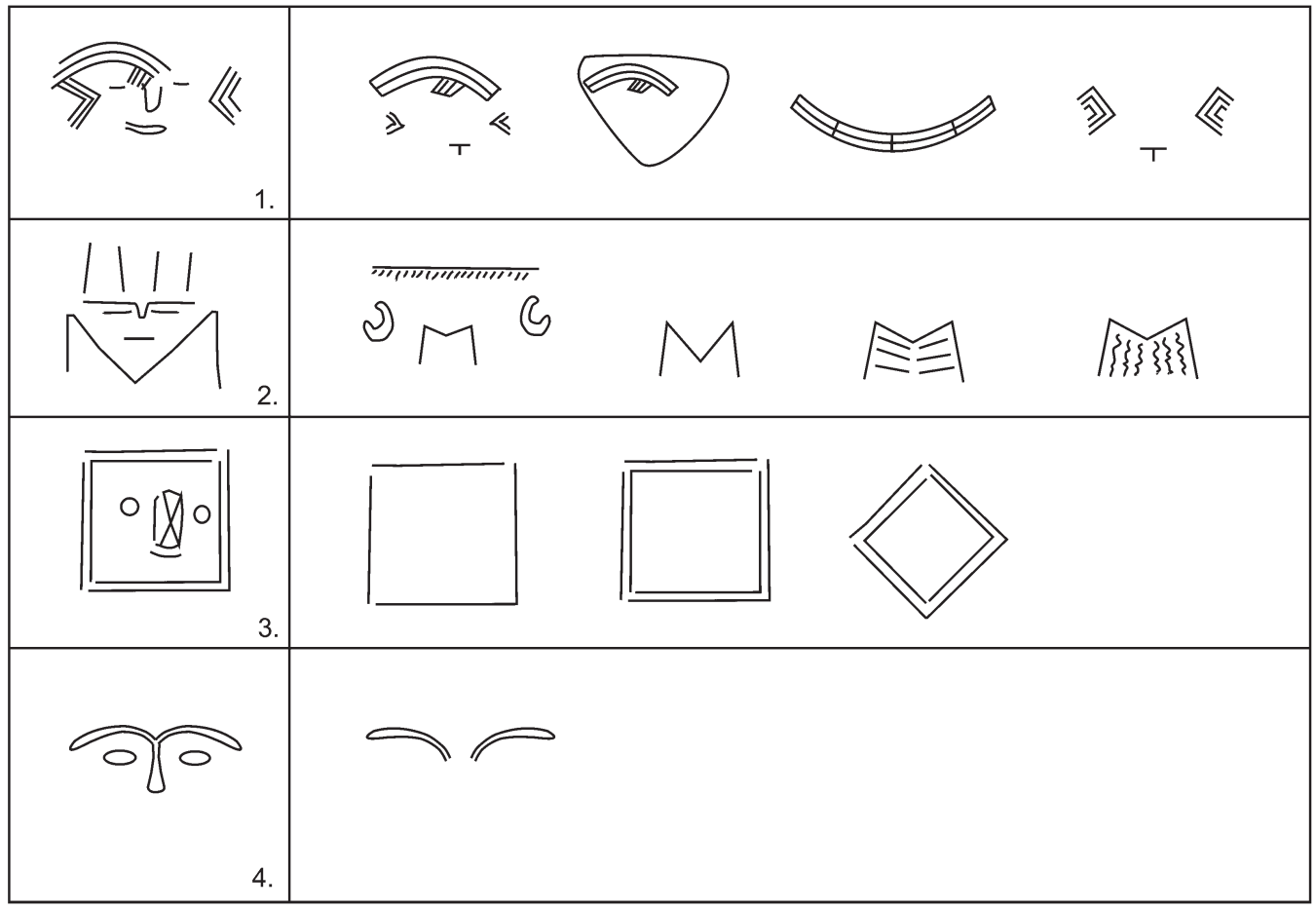

Tab. II: Characteristic motifs (features) connected with face depictions.

The analyzed face depictions are usually composed of combination of incised, plastic and painted elements. Finds with applied face motive made all by painting don't occur in the area of Carpathian basin, the closest analogies comes from central and especially South-Eastern Balkan.

Face vessels of Carpathian basin and its surroundings are characterized by triangular composition of face features consisting of primary elements of depiction (eyes, nose and mouth). In some cases, this composition is applied directly to the gently bulging triangular surface as mentioned above (i.e. Kalicz - Makkay 1977, fig. 186: 2, 7). These elements make a very consistent impression which didn't depend on pottery size and shape and these main facial features are always within a 15-centimeters distance from each other.

The scope of this article focuses on secondary features of facial depiction (characteristic motives related to facial depiction) that are more important due to the absence of first category. These do not necessarily have to be represented in each specimen, however they complement the overall impression of an anthropomorphic motive and contribute to easier legibility (tab. II).

I am assigning to this category a plastic rib framing the face depiction from upper part, less common facial components (ears, hair, chin) and naturally the symbols in the lower and upper part of the face or within its proximity. Contrary to primary elements of depiction, that do not include painted features in Carpathian region, we encounter application of paintings in secondary features - most often with yellow or red colors and in the Eastern linear region, we also find application of black color. 


\section{Characteristic motifs of facial depiction}

When observing specific ornamentation related to facial depictions, we need to focus our attention primarily on the approximate area of the face - individual features are usually concentrated around central depiction of the face and they mostly differ from the ornamentation found on the remaining part of the vessel, as well as decoration of ordinary ceramics typical for particular Middle Neolithic cultures (communities). I would like to emphasize, that same specific features may be present also in case face (primary elements of depiction) is missing and we can distinguish these finds from ordinary ceramics inventory on the basis of these indicators. I am presenting characteristic examples of their application related to each feature using so called "genuine face containers" (they are mostly well known examples) and complementing them with analogous so called "assumed face vessel" corresponding to their chronologic and geographic characteristics.

\section{The plastic rib}

The plastic bar occurs just under the rim of the vessel or in the place of the largest bulge and it complements facial depictions of Western Linear Pottery culture but primarily specimens found in area of the Želiezovce group and Szakálhát culture. Similar findings can not be found in other cultural habitats. The plastic bar is typically connected with plastic nose forming a characteristic letter " $\mathrm{T}$ " pattern. The bar is most often straight, horizontal with the exception of several fragments found in Moravia region and one artifact from Bad NauheimNieder-Mörlen site in Germany (Schade-Lindig 2002, fig. 5) where the bar above eyes is more or less arched. The plastic bar can be also iden- tified on face vessels originating from Eastern part of Carpathian basin, particularly within the area of The Eastern Linear Pottery culture, Bukk and Tiszadob cultures, however in these communities the face is framed by bar from below creating patterns similar to letters " $U$ " or "V", in extreme cases it may be directly applied to three-dimensionally raised triangular surface (fig. 1). Faces stylized this way also occur on self-standing figurines called "flat idols" known from all phases of The Eastern Linear Pottery culture, characterized by brick-shaped bodies and triangular heads.

Similar feature does not occur within the context of ordinary ceramics related to aforementioned cultures (groups). Therefore, I consider it a specific motif related to face depiction. This claim and the correlation of the plastic bar with face motif itself are illustrated by multiple findings from area of Transdanubian Linear pottery and Želizovce group ceramic style, where individual face features are absent, however an accentuated plastic bar still remains in its original shape (Cheben 2000, tab. 10: 170/17). More motifs with bold plastic borders in the shape of the letters "U" or "V" originate also from Eastern Linear Pottery region, specifically from Tiszadob and Bukk culture. I would like to emphasize that all aforementioned communities have been well known for findings of "real face pots" that have been found in identical archeological contexts (i.e. Lichardus 1974, fig. 18: 3-4; Csengeri 2011, fig. 10:1, 11; Šiška 1989, fig. 40:2).

\section{Arched incised symbol}

In the Upper Tisa region within the archaeological context of the emerging Eastern Linear Pottery, Bukk and Tiszadob culture we encounter a characteristic set of signs depicted with the utmost attention to detail on both face pots and triangular face depictions of flat idols. This de- 


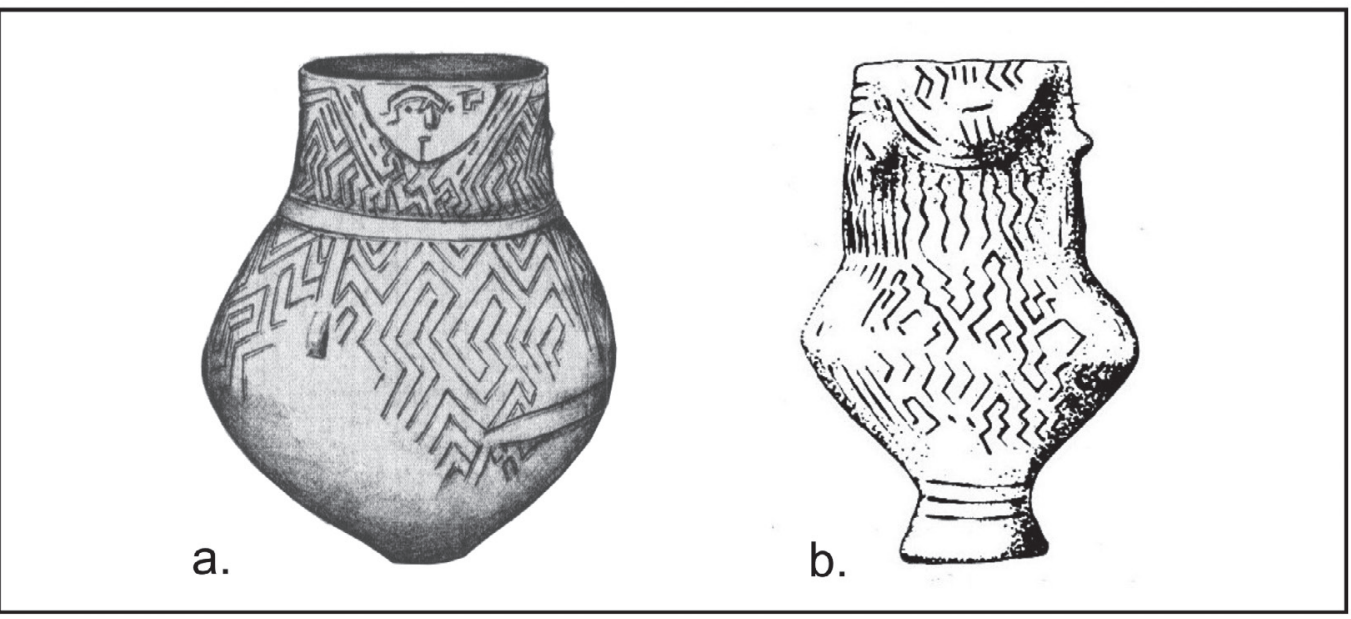

Fig. 1: "Real" and "assumed" face pots. 1.a - Mezőzombor - Temető; 1.b - Kenézlő (according to: Raczky Anders 2003, fig. 3: 1; Kalicz - Makkay 1977, tab. 186: 7).

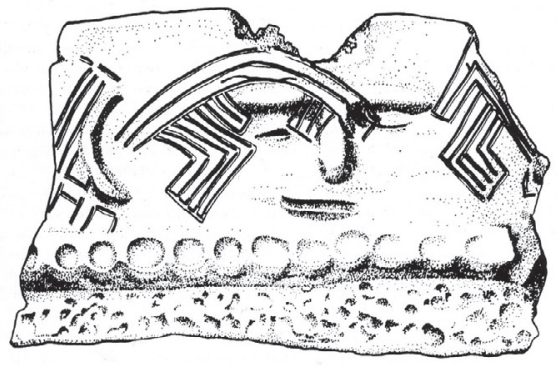

a.

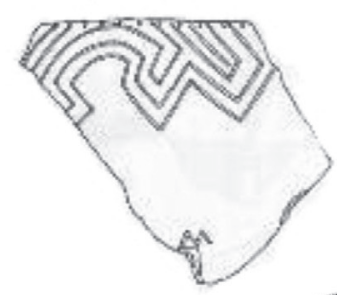

b1.

b2.

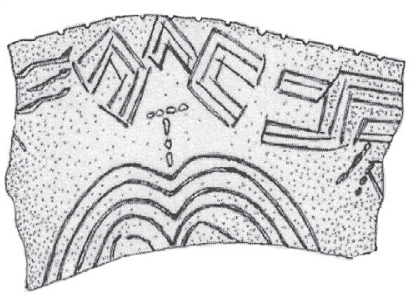

Fig. 2: Fragments of "real" and "assumed" face pots. 2.a - Füzesabony - Kettöshalom; 2.b1 - Šarišské Michal'any; 2.b2 - Garadna (according to: Kalicz - Koós 2000, fig. 9: 1; Hreha - Šiška 2015, tab. CXXIV: 266/7; Csengeri 2011, fig. 8: 3).

piction consists of incised arched sign branching at the nose. Both sides of the face may be framed by similar multiple incised lines in the shape of letter "V", leading up to the face. When we take a closer look at face depictions of the Eastern Linear circle we can conclude the occurrence of short vertical incised line in the lower por- tion of the face. Mouth depictions do not occur on majority of the finds and the line is placed right under the nose (it may be doubled up). Therefore, I maintain the opinion that this motif does not primarily relate to the mouth, although we still do not understand its meaning. Despite of the frequency of its occurrence in respect to 
secondary elements of face depictions, this particular line has not been yet presented, whereas in the context of ordinary ceramics no similar elements appear in the inventory of mentioned cultures (groups).

We can identify an identical arched motive maintaining the shape, size and composition of the entire set of signs also on "supposed face pots" (fig. 2). Just like in the previous case, it concerns fragments originating from sites with high concentration of "real face pots" findings. Approximately 15 specimens originate from late Tiszadob - Bukk settlement of Garadna (Csengeri 2010, 2011) in the northeastern Hungary. We observe even higher number of findings of this ceramic style from Šarišské Michalany site (Hreha - Šiška 2015, 71-72). Although in some cases arched sign may appear less consistently depicted, we need to take into consideration a certain degree of stylization, the complexity of the motive itself and admittedly, the individual craftsmanship of its makers. We need to emphasize that in a vast majority of "assumed face pots" occur also incised " $\mathrm{T}$ " sign placed within a certain distance under the arched motif - at least three such fragments can be observed at Domica site (Bárta 1957, tab.2: 2, 5, 14).

\section{Incised " $M$ " sign}

A characteristic feature of face depiction of "real face pots" in the area of Szakálhát culture is represented by an incised "M" symbol framing face from below. On five or six fragments (Szénászky 1990, 154-159), between eyes and nose two engraved triangular shapes facing down can be observed. A similar decorative element is not known from any other communities and we need to mention that it can be identified only in findings from Battonya region (Párász and Vid settlement sites); it is therefore very likely that this is a specific regional uniqueness.

Exactly the same sign in the shape of letter "M" placed under the face is characteristic also for Želiezovce face vessels. In this particular group, however, we encounter rich decorative engraved motifs consisting of multiple incised straight or zigzag lines, filling out the space under " $\mathrm{M}$ ", which can not be found in Szakálhát area. These parallel lines appear in the lower part of neck, in the case of half-spherical bowls under the largest bulge and evoke a beard according to some authors (Kuzma 1990, 447). It represents a rather frequent motif that may be even accentuated by painting - the lines were usually covered with layers of red and yellow color. Although incised lines represent a common decorative element, such extensive ornamentation can not be found on "ordinary" vessels. Since they are delimited with an engraved "M" (symbol) and they do not occur on the rest of the pot, I assume that they are related with this symbol and they complement, eventually highlight its meaning.

It is a curiosity that there still has not been a known case of a depicted " $M$ " sign with an absent face found in Želiezovce area. The question still remains: to what extent does this situation relate to the state of research and preservation of individual findings. However, concerning findings of this group, we may conclude that there is definitely a strong connection between "M" sign and face depiction.

Paradoxically, in the ceramic inventory of Szakálhát culture we encounter some findings where face is absent, however the engraved "M" sign remains unaltered (fig. 3). An ideal example is a set of 6 cylindrical pots from various Late - Szakálhát settlements sites. They are all of small dimensions with entire surface decorated by geometric patterns. The face has been depicted in traditional "Szakálhát style" on two of them but on remaining four vessels is completely missing (Hegedüs 1981, 3-12, fig. 6). 


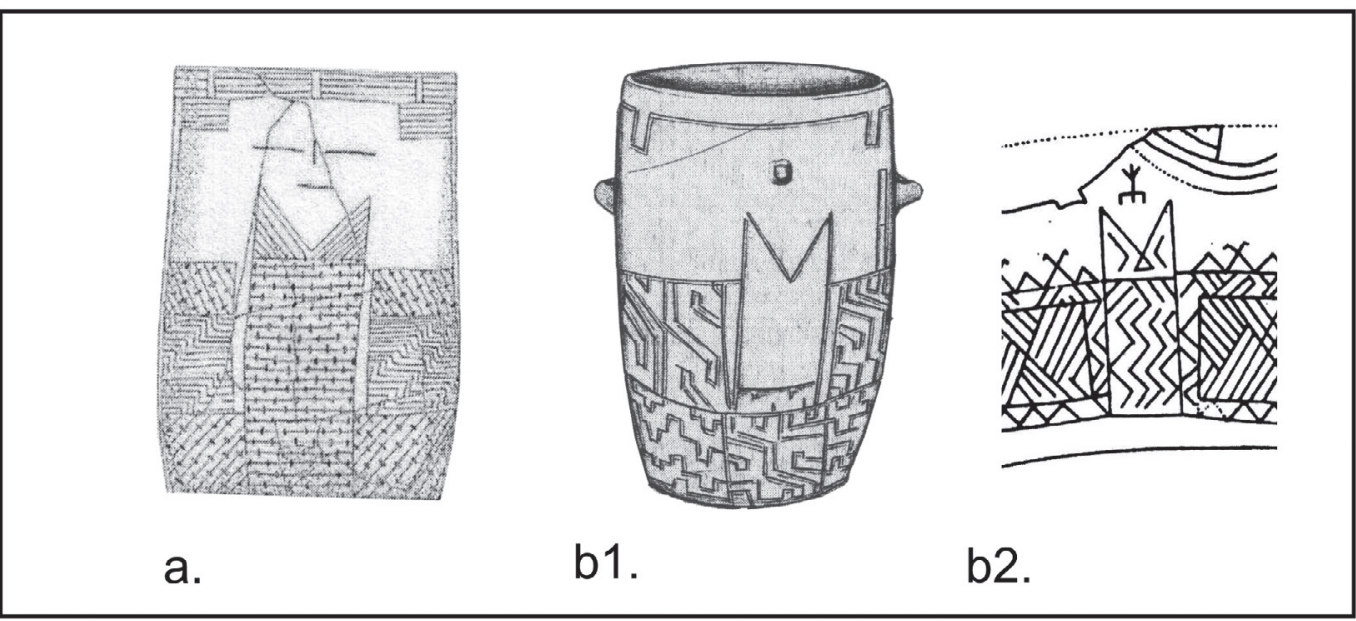

Fig. 3: "Real" and "assumed" face pots. 3.a - Abony-Serkeszék dűlö; 3.b1 - Csanytelek; 3.b2 - Battonya Gödrösök (according to: Sebők - Kovács 2009, obr. 1-2).

\section{Depiction of less common facial features (ears, hairstyle)}

Despite the fact that depiction of ears is almost an exception, we can identify it in some cases. The occurrence of applied plastic ears on "real face pots" found in the Carpathian Basin area is considered by authors Gy. Goldman a J. Szénászky (2002, 55-61) an unusual phenomenon and in this respect the influence of Early-Neolithic Starčevo culture. In the Middle Neolithic, depiction of ears can be observed on face storage jar from Szakálhát settlement in Gyoma-Özed (Goldman - Szénászky 2002, 56). The profilation of neck part and placement in a greater distance from the primary elements of face motive make an impression that from the frontal view, the whole stylization appears very realistic. The curiosity with this finding is the presence of openings in the lower part of both ears that suggests the idea of earrings or pendants which may have been placed inside them. In this respect, it is the unique finding with no analogies from the Carpathian Basin and the closest related findings can be found in
Central Balkan region (Berciu 1966, 98, fig. 6; Vasić 1936, 52, fig. 105).

A plastic applied ear, though without openings, is observed on fragment of Želiezovce group from Iža-Vel'ký Harčáš (Pavúk 1969, fig. 34: 2). Only one similar specimen was identified in the Eastern Linear Pottery circle, in particular in Füzesabony-Kettőshalom site (Kalicz - Makkay 1977, 129). A completely different fragment of the Tiszadob group comes from Šarišské Michalany (Šiška 1989, fig.39: 2), where ears are suggested by subdivided plastic rib in the shape of letter " $V$ " bordering the face from below. In our database, the notion of tongue depiction occurs only once - in connection with previously mentioned fragment. S. Šiška describes it literally as "sticking out tongue" (Šiška 1989, 107-110). It is depicted by an engraved formation similar to inverted letter " $U$ " which can be found on the chin, whereas the expected mouth is not depicted.

It is surprising that despite of low number of "real face pots" which contain this secondary element, we encounter more "supposed" findings with depicted ear. In all of these cases, the 


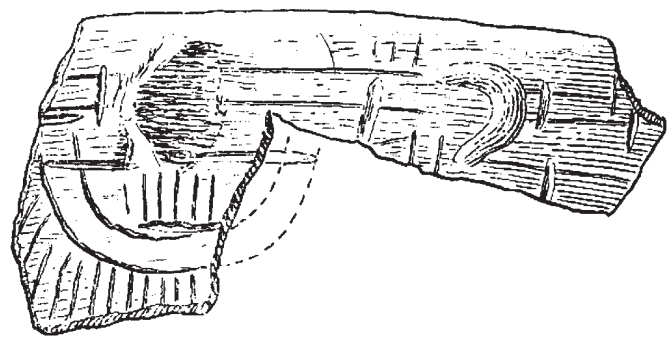

a.

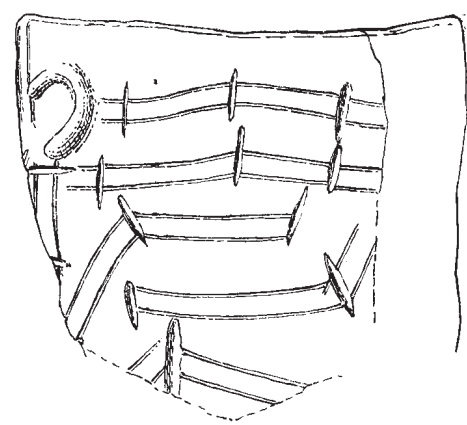

b.

Fig. 4: Fragments of "real" and "assumed" face pot. 4.a-b - Iža - Vel'ký Harčáš (according to: Pavúk 1969, fig. 34: 2, 9).

specimens come from Želiezovce and Tiszadob settlements and are preserved in a very fragmented state (fig. 4), therefore it is not possible to establish the size and shape of the vessels. We can only suppose there were no considerable differences between "real face pots" which were usually small to mid-sized bowls, semispherical or amphora-shape.

\section{Hairstyle}

Multiple incised lines found above the face are sometimes interpreted as a deliberately depicted more or less sophisticated hairstyle. When formulating similar assumptions, we need to take into account a certain amount of subjectivity that an author presents in his study, although I do not claim that it is a-priori incorrect, we still need to consider this thoroughly and develop a critical and reflective approach.

While some fragments of Želiezovce group may suggest an attempt to depict a coiffure (Cheben 2000, tab. 28, 227: 1), in the case of Szakálhát cylindrical storage-jars, short in- cised vertical lines below the rim encircling the neck part are common decoration pattern commonly applied to "ordinary" pottery. Therefore, it is more probable that it represents a decorative element in this particular ceramic style.

We need to emphasize that the identification of "assumed face pots", especially of small size fragments based on depiction of similar less characteristic face features may be misleading, because these may not necessarily be depicted in the same fashion within one culture or group.

\section{Separating the neck part of the vessel and bordering the face pannel}

Although separating of the neck part from the shoulders and the body of the vessel is not one of typical identifier we may observe this featue at some specimens comming from different ceramic styles. If the bordering is depicted it usually consists of one or two incised, rarely also painted lines. In few cases we may distin- 


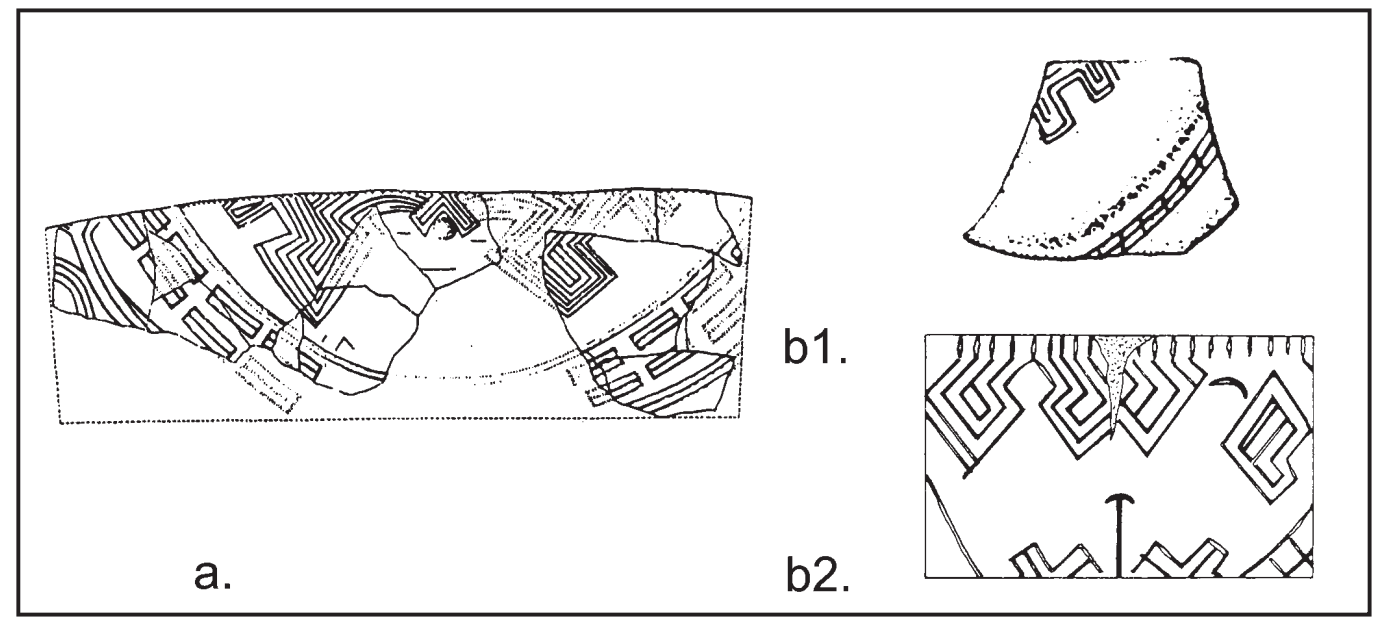

Fig. 5: Fragments of "real" and "assumed" face pots. 5.a, b2 - Domica; $5 . b 1$ - Gáva (according to: Lichardus 1974, fig. 17, 18: 4; Kalicz - Makkay 1977, tab. 186: 10).

guish also plastic band decorated with finger indentations. This form is characteristic for small and middle amphora-shaped vessels and biconical pots with high neck of Eastern Linear Pottery culture as well as Szakálhát storage jars. We need to emphasize that this feature occures also on „ordinary“ ceramics inventory of abovementioned cultures, therefore we assume there is no primary connection between this feature and face depiction.

However there is another more complicated decorative feature connected to face motif - intentional bordering of face panel. The best example represent specimen of Bukk culture found in Domica cave (Lichardus 1974, fig. 17) where the complex ornament consisting of two rows of incised rectagular pattern can be seen. Similar, even more simle forms of bordering of the face motive occure also in the case of "assumed“ face pots as many examples especially from Tiszadob and Bukk culture proove (fig. 5).

\section{Different decoration of the frontal (face) side and the back side of the neck}

We encounter different decorative features of "real face pots" in the front and back side of the neck especially in Szakálhát culture. Face side is usually lined from below by meander patterns or spiral motifs, while the entire surface of the back is covered by geometric elements. On some specimens, red and yellow painting have still been preserved (Csallány 1939, 145147, tab. 15: 1-2; Goldman - Szénászky 2002, 55-61, fig. 4). Division between front and rear part of the pot's neck is often accentuated by plastic applications, most notably small handles or plastic knobs lining both sides of the neck (Kalicz - Makkay 1977, 157, tab. 189: 7). In some cases they may take on a zoomorphic form $(\mathrm{Ka}$ licz - Makkay 1972, fig. 8: 1-2).

Very common feature of Szakálhát face pots is a pair of parallel incised ovals placed on the back side of the cylindrical neck or on the back side on the shoulders of vessel. This sign has been described as "double band" (Hegedüs 1981, fig. 3). The motive is not tied to the size 
or shape of the vessel itself - it appears on cylindrical pots of small measurements as well as necks of large jars, however it is undoubtedly related to the "idea" of face vessels since it appears not only on "real" but even more frequently on "assumed" species (fig. 6). It is notable that in the Eastern Linear pottery circle, the "double band" can be found even on the back side of the flat idols (Raczky - Anders 2003, 167, fig. $6: 1,3 ; 7: 1$ ) creating a unique linkage between self-standing anthropomorphic finds (idols, figurines) and pottery with anthropomorphic applied motifs.

In the case of above-mentioned flat figurines, along with double band appears also an arched symbol placed mostly on the right side of the face. This combination of signs is accompanied with depiction of female sexual features. When we accept a hypothesis that figurines depicted in this fashion represent females (real or impersonated figures), a mirrored motif as seen on the face pot from Füzesabony-Gubakút site could symbolize male figure. Naturally, the verification of similar theories requires a further detailed study of many more examples, including a revision of already known specimens found in the first couple of decades of $20^{\text {th }}$ century when research articles did not always contain detailed information about decoration of back parts of self - standing figurines or face vessels. It is a fact, however, that in relation to common ceramics we do not encounter similar features and decoration consists of cyclically repeating incised spiral motifs, hence we may consider this feature as one of the identifiers.

The necks motifs of face pots from Western linear circle are relatively varied, in contrast to almost uniform depiction features of Eastern Linear pottery style and the state of preservation in most cases makes the analyse almost impossible. We do not identify any different motifs of front and back sides of the vessels. Face pots are decorated by sim- ple patterns consisting of incised zigzag lines which can be spotted on common ceramics as well. In this respect, amphora - shape vessel from Močovce (Škrdle 1926, fig. 164) can be considered an exception. A unique decoration is created by two perpendicular incised "swastikas" oriented in a mirror-like fashion, creating a symbol similar to letter " $H$ " right under the face depiction. The front and the back side of the neck are different from each other and are separated by a pair of vertical lines filled out by horizontal waves. A face fragment from Patince with neck perforated across the entire surface with small perforations is considered to be unique specimen as well. Even though the remaining part of vessel has not been preserved, J. Pavúk (1969, 310 ) interpreted it as a fragment of strainer. This is a very untraditional and there are not any analogies for such finding.

On the latest face pots from Eastern part of Carpathian basin we do not observe any specific motifs or decorative elements pointing to an affiliation with face depictions. The face itself is framed by an incised square often filled out from inside by additional, usually multiple lines, while the rest of the neck is covered by complex geometric patterns, typical for "common" ceramics found in the area of the Tisza culture.

\section{Remaining part of the vessel}

Decoration of remaining part of the vessel (as well as its shape and size) is from the point of definition of face pots and "assumed" species less significant, since most specimens have not been preserved to the extent allowing detailed study.

Admittedly, many findings which can be reconstructed were found in Carpathian Basin region, yet these represent less than one half of our database ${ }^{1}$. Analysis of these artifacts 


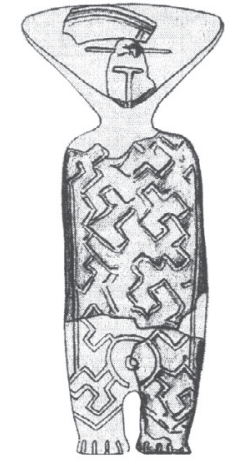

a.

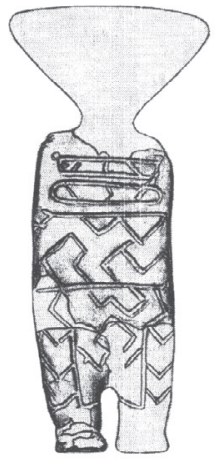

b1.

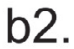

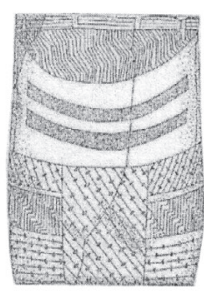

b3.
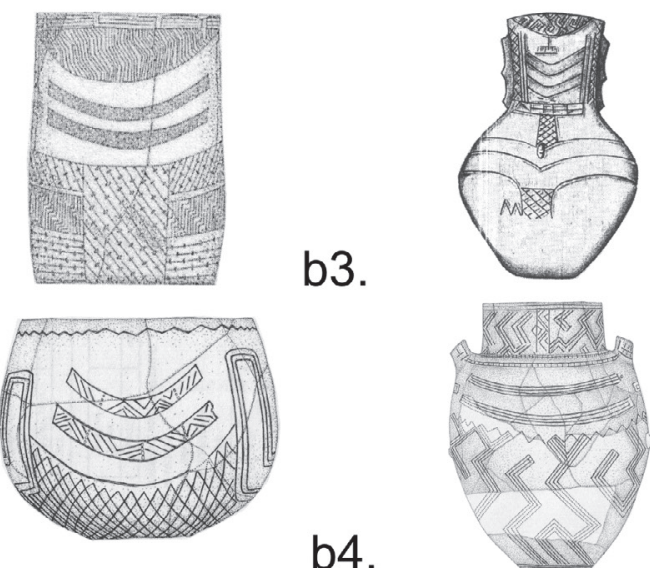

Fig. 6: "Double band" motive as found on Eastern Linear flat idol and both "real" and "assumed" face pots. 6.a Szarvas; 6. b1 - Abony-Serkeszék dűlö; 6.b2, b4 - Garadna; 6.b3 - Battonya - Gödrösök (according to: Raczky - Anders 2003, pic. 2: 1, 6: 3; Sebők - Kovács 2009, pic. 1: 2; Csengeri 2011, fig. 1,5).

could significantly contribute to aforementioned theoretical assumptions, still the lack of such findings does not grant a formulation of any definite or valid conclusions.

At any rate, so far the most plausible assumption is based on the fact that body part of face vessels is usually decorated by decorative features which are characteristic for particular ceramic style ${ }^{2}$ and the size and shape of face pots correspond with "common" pottery.

1) From a set of 142 "real face vessels" we may identify their shape in less than a half of the specimens (67). In all other cases, only its parts are restored - mostly a neck part with main decorative motifs. Others parameters can be only assumed on the basis of the rim diameter, the height of neck, eventually other preserved parameters.

2) While specimens of Eastern Linear Pottery, Tiszadob and Tisa culture are dominated by geometric motifs consisting of incised lines that make up complex forms decorating the majority of parts, or the entire surface of vessels, on findings of Bukk and Szakálhát culture prevail curvilinear motifs and spirals depicted in an artistic style corresponding to a particular ceramic style. With Transdanubian Linear Pottery and Želiezovce group,

It is conspicuous that decoration of face pots of Transdanubian Linear Pottery and Želiezovce group don't differ from ordinary ceramics inventory. 


\section{References}

Bánffy, E. 2001: Notes on the Connection between Human and Zoomorphic Representations in the Neolithic. In: Bertemes, F./ Biehl, P. F. (ed.): The Archaeology of Cult and Religion. Archeolingua 13, Budapest 2001, 53-71.

Bárta , J. 1957: Záchranný výskum v v záplavou postihnutej Domici. Študijné zvesti AÚ SAV 2, 29-33.

Becker, V. 2007: Early and middle Neolithic figurines - the migration of religious belief.

Documenta Praehistorica XXXIV, 119-127.

Berciu, D. 1966: Cultura Hamangia vol. 1. Editura Academiei Republich Socialiste Romania, 1966.

Bertemes, F. - Biehl, P. F. 2001: The Archaeology of Cult and Religion. Archeolingua 13, Budapest 2001.

Csallány, G. 1939: Gesichtsdarstellungen auf Gefäßen der Theißkultur. Germania 23, 145-146.

Csengeri, P. 2010: Settlements of the Bükk Culture from Hernád Valley, North-Eastern Hungary. Archeometriai Műhely 2010/4, 227-235.

Csengeri, P. 2011: Középső neolitikus arcos edények Garadnáról. Herman Ottó Múzeum Évkönyve L, 67-104.

Fábián, S. 2005: Arcos edénytöredékek a Zselizi kultúra lelóhelyéről, Sszécsény-Ültetŕsről. Archeológiai Értesítő CXXX, 5-20.

Garfinkel, Y. 1998: Dancing and the Beginning of Art Scenes in the Early Village

Communities of the Near East and Southeast Europe. Cambridge Archaeological Journal 8: 2, 307-237.

Garfinkel, Y. 2010: Dance in prehistoric Europe. Documenta Praehistorica XXXVII, 205-214.

Goldman, Gy. -Szánászky, J. 2002: Ein Gesichtsgefäß der Szakalhát-kultur. Budapest Régiségei XXXVI, 55-61.

Gimbutas, M. 1974: The Goddesses and Gods of Old Europe 7000- 3500 BC. London 1974.

Hegedüs, K. 1981: Újkőkori lakótelep Csanytelek határában. Archeológiai Értesítő, CVIII, 3-12.

Hodder, I. 1992: Theory and Practice in archaeology. Routledge 1992.

Höckmann, O. 2000-2001: Bandkeramische Menschenbilder: Göttinnen - oder? Mitteilungen der Anthropologischen Gesellschaft Wien 130/131, 77-92.
Hreha, R. - Šiška, S. 2015: Bukovohorská kultúra na Slovensku vo svetle výskumov v Šarišských Michalanoch a Zemplínskych Kopčanoch. VEDA 2015.

Cheben, I. 2000: Bajč- eine Siedlung der ŽeliezovceGruppe. Bonn 2000.

Kalicz, N. - Koós, J. 2000: Neolitische Gesichtsgefässe im Nordosten des Karpatenbeckens. Herman Ottó Múzeum Évkönyve, XXXIX, 15-44.

Kalicz, N. - Makkay, J. 1972: Gefäße mit Gesichtsdarstellungen in der Linienbandkeramik aus Ungarn. In: Bachmayer, F. - Ruttkay, E. - Melichar, H. - Schultz, O. (ed.): Idole: prähistorische Keramiken aus Ungarn. Wien, 9-15.

Kalicz, N. - Makkay, J. 1977: Die Linienbandkeramik in der Großen Ungarischen Tiefebene. Stud. Arch. 7. Budapest.

Kuzma, I. 1990: Plastika želiezovskej skupiny z MužleČenkova. Slovenská archeológia XXXVII, 429-450.

Lies, H. 1963: Ein Gefäß der Linearbandkeramik mit reliefierten Gesichtsdarstellungen von Barleben, Kr. Wolmirstedt. Ausgrabungen und Funde 8, 9-16.

Lichardus, J. 1974: Studien zur Bükker Kultur. Saarbrücker Beiträge zur Altertumskunde Band 12. Bonn.

Makkay, J. 1964: Early Near Eastern and South East European gods. Acta Archaeologica Hungarica. XVI, 3-64.

Pavli, I. 1966: Early „Myths“ relating to the Neolic Society. Archeologické rozhledy XVIII, 700-717.

Pavli̊, I 1997/98: Kultureller Kontext der Neolithischen Gesichtsgefäße im Donaubecken. SASTUMA 6/7, 111-131.

Pavli̊, I 2010: Obličejové amfory středoevropského neolitu v evropském kontextu. In: Šuteková, J. et all (ed.): PANTA RHEI. Studies in Chronology and Cultural Development of South-Eastern and Central Europe in Earlier Prehistory Presented to Juraj Pavúk on the Occasion of his 75. Birthday. Bratislava 2010, 601-606.

Pavúk, J. 1969: Chronologie der Želiezovce Gruppe. Slovenská archeológia XVII, 269-367.

Pavúk, J. 1981: Umenie a život doby kamennej. Dávnoveké umenie Slovenska (Ars Slovaca Antiqua) 13. Bratislava 1981.

Podborský, V. 1985: Těšetice- Kyjovice II. Figurální plastika lidu s moravskou malovanou keramikou. Brno 1985. 
Podborský, V. 2006: Náboženství pravěkých Evropanů. FF MU Brno 2006.

Quitta, H. 1957: Zur Deutung und Herkunft der bandkeramischen „Krötendarstellungen“. Varia Praehistorica, Forschungen Leipzig 2, 51-81.

Raczky, P. - Anders, A. 2003: The internal relations of the Alföld Linear Pottery culture in Hungary and the charakteristics of human representation. In: Jerem, E. - Raczky, P. (ed.): Morgenrot der Kulturen. Frühe Etappen der Menschheitsgeschichte in Mittel- und Südosteuropa. Festschrift für Nándor Kalicz zum 75. Geburstag. Archeolingua 15. Budapest, 155-182.

Remišová-Věšñová, K. 2008: K problematice interpretace antropomorfní plastiky neolitu. Praehistorica XXVIII, 145-175.

Sebök, K. - Kovács, K. 2009: Hengeres testű arcos edény töredékei a fiatal Szakálháti-kultúra Rákóczifalva határában feltárt településéről. In: Bende, L./ Lőrinczy, G. (ed.): Medinától Etéig. Tisztelgő írások Csalog József születésének 100. évfordulóján. Szentes 2009, 81-90.
Schade-Lindig, S. 2002: Idol- und Sonderfunde der bandkeramischen Siedlung von Bad NauheimNieder-Mörlen „Auf dem Hempler“ (Wetteraukreis). Germania 80, 47-114.

Szénászky, J. 1990: Arcos edényfedő Battonyáról (Deckel eines Gesichtsgefäßes aus Battonya). Archeológiai Értesítő, CXVII, 151-160.

Šiška, S. 1989: Kultúra s východnou lineárnou keramikou na Slovensku. Bratislava.

Škrdle, F. 1926-27: Nález zajímavé amfory na volutovém sídlišti v Močovicích u Čáslavě. Památky archeologické, XXXV, 547-550.

Tichý, R. 1958: Anthropomorfní nádoby z Mohelnice na Moravě a jiné poznámky $\mathrm{k}$ volutové keramice. Památky archeologické XLIX, 1-14.

Tomašovičová, T. 2012: Zobrazenie človeka na keramike v strednom neolite. nepubl. dipl. práca, Nitra 2012.

Tomašovičová, T. 2015: Vývoj antropomorfného dekoru na neolitickej keramike $\mathrm{v}$ prostredí karpatskej kotliny (vybrané aspekty problematiky). Acta Musealia 13, 6-31.

Vasić, M. 1936: Preistoriska Vinča II. Beograd. 


\section{Summary}

The aim of this short study was the identification of several characteristic signs (features) appearing in an identical form and corresponding ceramic style area on two types of artefacts - "true" face pots as well as "assumed" face pots. Based on these specific motifs which can be considered indicators, it is possible to classify ceramic fragments as face vessels despite the fact that the face itself may be intentionally absent or cannot be identified due to its poor state of preservation.

We can conclude that the whole idea of a face pot may be represented by three types of artefacts:

a) Face pot with applied face motif accompanied by characteristic signs (features)

b) Face pot with applied face motif where characteristic signs (features) are absent

c) "Assumed" face pot without face motif with accompanying characteristic signs (features)
Obviously, the most unambiguous finds are those from the first category; they are most popular for obvious reasons, however we often encounter less excellent examples of face depictions that belong to the second category. In regard to finds from the third category, no clear statement on this phenomenon has been published so far and categorization of these finds as "face" or "common" vessels appears to be based on subjective opinion of individual authors. Our intent was to pay attention to this systemically overlooked group of finds, which may contribute to an understanding of prehistoric symbolism. For individual Neolithic communities we can assume that vessels without explicit depiction of an anthropomorphic motif, but carrying a special set of characteristic signs (features), might have had the same symbolic meaning as "true" face pots.

Mgr. Terézia Tomašovičová, Ph. D.

- Pamiatkový úrad SR,

Cesta na Červený most 6., 81104 Bratislava

terezia.tomasovicova@pamiatky.gov.sk 